\title{
'He devours her with his gaze': Maurice Leitch's Stamping Ground and the Politics of the Visual ${ }^{1}$
}

In a 1994 edition of the Northern Irish magazine Fortnight, two up-and-coming Northern Irish novelists published polemical reviews of two novels: Glenn Patterson on Eoin McNamee's Resurrection Man (1994) and Robert McLiam Wilson on Maurice Leitch's Gilchrist (1994). Taken together, these effectively set out their manifesto for the representation of Northern Ireland in prose. Patterson was highly critical of McNamee's novel, a loose fictionalisation of the Shankill Butcher murders with a cinematic aesthetic, claiming: 'This is the city as cadaver ... a city whose mortification precludes all possibility of change'. ${ }^{2}$ Patterson continued to detail his views on the salacious and exploitative tone of the novel. On the opposite page, Wilson's review of Gilchrist was enthusiastic, but soon developed into an analysis of the reviewer and reviewee's place within the Northern Irish literary milieu. In this review, provocatively entitled, 'Rhythm Method', Wilson claimed that Protestant novelists lacked the 'cultural credit card' that he possessed, being 'born Catholic and working-class, so I've done well out of it, and the more battered and croppy boy I behave, the better I do. So I don't like to bite the hand that patronises me'. ${ }^{3}$ Turning to Leitch's work, then, he went on to say that 'The Protestant vision, the Protestant version, isn't popular. It's got no rhythm. It's white South African. It's too complicated. The Catholic version is familiar, more Irish somehow'.

Compared to his contemporaries Brian Moore and John McGahern, limited critical attention has been paid to Maurice Leitch's work. He has commented that 'My books still - this sounds like self-pity - get a dusty reception in the North, but I think that's very natural' ${ }^{5}$ Leitch has complained of Unionism's enthusiasm for 'religious censorship, sexual censorship, literary censorship. There's no difference whatsoever between the repressive religious ideologies ${ }^{\prime 6}$; moreover, he has clearly stated that 'Ireland is sexually repressed; let's face it' ${ }^{7}$ Commenting on

Irish University Review 44.2 (2014): 288-304

DOI: 10.3366/iur.2014.0125

(C) Edinburgh University Press

www.euppublishing.com/iur 
The Liberty Lad (1965) and Poor Lazarus (1969), which fell foul of the Irish Censorship of Publications Act (1967), he asserts that: 'I think if a novelist was writing at that particular time about what was going on in his environment, if he was youngish and wasn't banned, there was something going wrong somewhere because he was closing his eyes to what was going on around him'. ${ }^{8}$ In Forces and Themes in Ulster Fiction (1974), John Wilson Foster assesses Leitch's novels, lauding their candour in dealing with sexual issues and judging this frankness as a measure of 'Leitch's courage as an Irish writer'. ${ }^{9}$ In both of these novels, Leitch represents male friendship with a decidedly sexual edge, such as Frank Glass' friendship with gay Terry in The Liberty Lad, and Yarr and Quigley's dysfunctional relationship in Poor Lazarus. Whether in Frank's botched attempts to seduce a married woman in vacant houses, or Yarr's surreal fantasies after repudiating his wife, heterosexual intercourse in Leitch's novels is thwarted by awkwardness, repression, and latent misogyny. Leitch's male characters are at odds with their desires; in preTroubles Northern Ireland, they can find no sexual release and, in the case of the protagonists in Poor Lazarus, have difficulty maintaining mental stability as a result. Unsurprisingly, both of these novels were banned in the Republic of Ireland. ${ }^{10}$

Leitch's fiction represents and is self-critical about rural Protestant life in mid-century Northern Ireland. ${ }^{11}$ Barry Sloan situated Leitch's fiction within a continuum of Ulster Protestant writers such as John Hewitt, Sam Hanna Bell and Derek Mahon ${ }^{12}$ and has commented on Leitch's vision of Northern Ireland: 'Leitch has sensed and conveyed terminal decay, sullen hatred and sour futility in his region' ${ }^{13}$ Leitch is, of course, not alone in his depictions of the sterility of rural life in Ireland in the mid-twentieth century. Kavanagh's Tarry Flynn (1948) and Sam Hanna Bell's December Bride (1951), for example, represent the perceived torpor of the period. Leitch, like John McGahern, intersperses flashes of the most extreme brutality in his narratives of rural life and it is significant that Leitch chooses to set his novels of repression and desire in the Ulster countryside. Indeed, the central character of Stamping Ground, Hetty Quinn, exhorts that: 'All these things tightened around her, tight wee place, tight wee people, tight, tight, tight... ${ }^{14}$ Just as the rural is privileged in Irish Nationalist discourse and seen as somehow more 'authentically' Irish than the city, an analogous process occurs in the Ulster Protestant imagination, for which the symbolic trajectory of the Orange Order parade each year is out of the city to 'The Field'. Neil Jarman argues that the 'march to the Field ... represents an abandonment of the city and its profanities for the purity of the countryside, where spirits are refreshed away from women and heathens. Renewed in their fortitude, the men can 
recolonise and reassert their control over the city for another year'. ${ }^{15}$ Leitch's fiction, then, turns rural privilege back on itself and is both self-critical and self-reflexive about Protestant hegemony.

Maurice Leitch's novel, Stamping Ground, was published in 1975 and was written during some of the most dramatic years in Northern Irish history. The title of the novel also belies its ambiguous intentions. Stamping Ground has obvious violent connotations, but it is also a familiar phrase, used to recall a place of youthful enjoyment. It can also be compared to Heaney's metaphor in 'Act of Union' from North (1975), where he describes 'the big pain/ That leaves you raw, like opened ground, again'. ${ }^{16}$ Indeed, so pleased was Heaney with the term 'Opened Ground' that he used it as the title of his selected poems: the opening or breaking of ground has obvious symbolic cachet in the Irish literary canon. Embedded in this ambiguous title, is the problem of how to make misanthropic novels about frustration and sexual aggression in the Ulster countryside saleable. It is a problem the first publishers of his novels did not solve well. The first cover, from Abacus, features a scene of rolling hills, lush foliage and a comely young girl sitting casually on a fence in a cobblestone wall. She looks directly at the reader, expressionless, with a shoe dangling from her foot. We can just make out three figures in the background toiling gathering hay. There is no indication of the brutality that will occur before the end of the first chapter. Similarly, the back cover has the events of the narrative euphemised as 'the yearnings of adolescence' and even goes so far as to quote a reviewer describing the novel as 'sensuous, almost somnambulistic'. The novel's epigraph 'A road, a mile of kingdom, I am king/ Of banks and stones and every blooming thing' is from Patrick Kavanagh's 'Inniskeen Road: July Evening'. In this poem, Kavanagh negotiates the role of the rural poet, juxtaposing his life and work. Arguably, though, this novel has more in common with Kavanagh's later The Great Hunger, as both share a pre-occupation with an unsentimental vision of the rural life. ${ }^{17}$ The epigraph, however, prepares us for a predictable country saga, not, as George O'Brien asserts, a novel which 'unmasks the pathologies of the Northern psyche as expressed through sexuality and violence in a rural setting ${ }^{\prime 18}$

The novel opens with what appears to be a charming bucolic scene, of young men (Harvey Gault, Mack McFarlane, and Frank Glass) ${ }^{19}$ toiling in a field on a hot summers' day. This opening scene uses sensual, evocative language of the body and violence, 'strong swelling of blood and heavy handed power'. ${ }^{20}$ Leitch goes on: 'They were destroying that pleasure and pattern; they were raping the rows faster and faster, racing out to the perimeter of their previous raids, then back to the growing heap' ${ }^{21}$ The men's work is temporarily 
interrupted by the visit of local girl Hetty Quinn, charged with bringing sustenance to the working men. The pivotal event that shifts the narrative is her sexual assault at the hands of these young men, as they conspire to chase her, knock her off her feet, and pull at her clothes:

Then they were all on top trying to touch her, contain her beneath their weight, as she flailed and screamed, muffled now but still a frightening sound and he had to admit, arousing too.... Boldness grew in him, roughness too; he knew hands couldn't be identified.... He burned for a part of her for his own and squeezed cruelly in consequence. ${ }^{22}$

This first assault acts as a parallel to the later, more serious, attack at the end of the novel. After this assault, Hetty notes: 'It was strange and she didn't know how to explain it, but she wanted to keep herself naked to the waist for as long as possible, as though to show someone, something, how she had been treated, now that it had been done to her to display herself, look what they have done, look, look!'23 This incident, then, demonstrates the two main ideas the novel will explore. The first is Hetty's wish to be seen and the politics of the visual, which will influence the rest of the narrative. The second is the presentation of the three male characters as interchangeable ('He knew hands couldn't be identified'), opening the climactic scene up as a critique of masculine hegemony and, through that, Unionist hegemony in Northern Irish political life. The time at which Leitch was writing saw a renegotiation of this and a 'threat to certain local apparatuses of Protestant domination' ${ }^{24}$ In presenting three interchangeable assailants, Leitch foregrounds the problem of identification in the novel. This is, of course, magnified during the depiction of sex acts, with the male viewer not wishing to be forced to gaze homoerotically on another male or identify with an assailant, thus taking responsibility for these acts. As Laura Mulvey states:

The male figure cannot bear the burden of sexual objectification. Man is reluctant to gaze at his exhibitionist like ... In contrast to woman as icon, the active male figure (the ego ideal of the identification process) demands a three-dimensional space corresponding to that of the mirror recognition, in which the alienated subject internalised his own representation of his imaginary existence. ${ }^{25}$

In rendering his assailants as one amorphic yet phallic mass, Leitch carefully avoids any hint of homoerotic identification and, instead, 
allows the attack to be read in terms of wider patriarchal structures. For Lacan, the phallus is the prime signifier when discussing the language of power and authority; it signifies (when absent) the lack of agency and (when present) the name-of-the-father, through which the subject gains their role in the symbolic order and, by extension, culture. The penis is not the same as the phallus as it can, crucially, fail to work. The men in Leitch's fiction tend to be fruitlessly chasing phallic agency only to be thwarted by it, both in terms of maintaining their hegemonic dominance and, literally, in maintaining an erection. Through brutish behaviour they attempt to recapture their lost agency: 'An idea of woman stands as lynchpin to the system: it is her lack that produces the phallus as a symbolic presence, it is her desire to make good the lack that the phallus signifies'. ${ }^{26}$

The theory of the visual usually concentrates on the mass production of images and desire, but in this novel the visual functions as something more intimate. Photographs are kept as memento mori or to mark posthumous authority, and the townspeople are covertly scrutinised and catalogued. The text functions as an archive of described images, which link to Derrida's postulation that the wish to preserve and make public is borne out of a desire to locate an original patriarchal form of authority. ${ }^{27}$ There is certainly a wish in Leitch's fiction to re-author dominant narratives of Northern Irish identity whilst maintaining a binarised understanding of gender. Leitch has Barbour Brown compile a literal archive, the 'book of the Valley ${ }^{\prime 28}$, which began as a modest history and has now evolved into a record of his own misanthropy and further proof of his debased view of human existence as the found himself unable to accept the smug circling continuum of such existence; out of the womb, aloft for a brief spell, then back into the soil again'. ${ }^{29}$ His archive is a stand-in for the life and authority he never had.

While it would be wrong to suggest that sex and violence are coterminous only in Northern Irish fiction, it is worth noting the prevalence of sexual aggression in the novels written and set in the province. John Wilson Foster recognises the ways in which these themes are readily explored in the Northern Irish novel: 'Any fiction writer who wants to illuminate Ulster society has to press realism and psychology into service in the exploration of three things: sex, violence and sectarianism'. ${ }^{30}$ Foster also notes that 'Violence is simply part of the fictional vision of Ulster, and perhaps, too, an easier dramatic catalyst to handle than the more sensitive mysteries of $\operatorname{sex}^{\prime}{ }^{31}$ In addition to the central acts which drive the narrative, sexual deviance is everywhere in Leitch's countryside, particularly those aspects of rural life usually associated with Catholic communities, such as abuse and illegitimacy ${ }^{32}$. In the novel, the symbolic Protestant patriarch exploits his power in his own home and is abusive, with the two main 
female characters, Hetty and Minnie, for instance, were abused by father figures in their homes. Edna Longley comments on the patriarchal nature of the Ulster Protestant community with 'its cult of male chieftains: Carson, Moses, Paisley the 'Big Man' ... the whole country bounds in Ancient Orders of Hibernian Male Bonding: lodges, brotherhoods, priesthoods, hierarchies, sodalities, knights, Fitzwilliam Tennis Club, Field Day Theatre Company'. ${ }^{33}$

We are told about an illegitimate child, born to a mentally disabled young woman, and the tone borders on the inappropriately leery:

What sort of brute could have fathered it, he wondered, taking her in some ditch or barn or pressed up against some wall or tree in the dark fields. And what could have brought him to it? Drink leading to blind lust, or a patient stalking until the occasion seemed right; muffling her, covering and forcing his way? Then, ignorant and animal pain. Or perhaps something unthinkable, which seemed to him somehow more disturbing - compliance and enjoyment? ${ }^{34}$

This narrative voice serves to make us unsure whether this is Leitch's or the schoolteacher Barbour Brown's prurient thoughts and how complicit we, as readers, are in the processes of secrecy and identification. Leitch also shows the lack of legal redress that existed for rape victims when describing a girl who has been attacked during World War II: 'That girl that time with those coloured soldiers after the dance in Antrim. She had to emigrate. They said she would never be the same again ... She even hears voices saying, she must have encouraged them. They said that about that other girl and the six G.I.'s' [sic]. ${ }^{35}$ Diarmuid Ferriter chronicles the legal issues surrounding sexual assault and incest in Ireland in the 1950s and 60s, noting that there 'remained little public discussion of the sexual abuse of young girls, which continued to occur on a regular basis, with devastating consequences for the victims who were often deemed, it seemed, to share guilt' and young victims being 'associated with sexual immorality' and hidden from view as a result. ${ }^{36}$

Leitch represents the needs, wants and desires of his protagonists as animalistic and base and frequently compares his characters to animals (Barbour as a lecherous goat, the boys as bucks, Hetty as a wild horse that needs to be broken in). This constructs them as subject to their bodily desires, rather than the clean and proper bodies, transcending the flesh, of Christian theology. Barbour thinks of himself as: 'An old goat too immersed in his own skin, picking among his own detritus, a walking rubbish-tip of scurf, nail-parings, nose-pickings, ear-wax and toe-dirt'. ${ }^{37}$ Barbour is acutely aware of the decline of 
his body, and incontinence seems a particular worry for him: 'Was he entering, or had he already crossed into, his second childhood? The phrase itself sounded, looked, delightful. A state to be embraced, with its implications of new innocence and a carefree return to an earlier golden age - but it was fraud. Reality was twitching limbs, incontinence and others' disgust' ${ }^{38}$ Like Wilson's 1989 creation, the eponymous Ripley Bogle, Barbour Brown is obsessed with his own falling apart and the loss of his masculine agency through the loss of bodily cohesion. Barbour has displaced feelings of impotence and ageing onto his relationship to his own body. He is obsessed with the maintenance of the hard working clean Protestant body and often ties his wish to be spotless back to his religious identity:

A man and his needs. His needs were simple, spare; they seemed to dwindle as one aged. Reduced at last to filling the belly and emptying bladder and bowels. God spare him that. There were tales of old people being found like animals in a stall. First thing to be done was wash them (curious the priority) scrub them down, ignore their cries as the layers came off. Not easy to acquire that patina, year after year of wood smoke, dried soap scum, tobacco juice - tears too. And the final result - a being fit to meet his Maker, clean and Protestant looking. ${ }^{39}$

Brown's wish to maintain his bodily continence and meet his maker clean and complete aligns with Julia Kristeva's concept of the 'clean and proper body'. ${ }^{40}$ In order to maintain the distance between self and other, one must be on constant guard to withstand polluting objects, such as excrement, menstrual blood and one's own filth. As Kristeva contends 'Excrement and its equivalent (decay, infestation, disease, corpse, etc.) stand for the danger to identity that comes from without: the ego threatened by the non-ego, society threatened by its outside, life by death'. ${ }^{41}$ When Barbour Brown fears being old, incontinent and abused in a nursing home like 'a dumb football to be bumped about ${ }^{\prime 22}$, he is displacing his fear of powerlessness. He is terrified of becoming an object and tries to maintain his own bodily coherence through objectifying others. Any attempt to reconcile his real and imaginary world disconcerts him: 'It made him shy of meeting people face to face - even past acquaintances - of talking to them. Exchanging a common greeting about the state of the weather could constitute a major defeat in the course of a day's campaign of secrecy'. ${ }^{43}$ He wants to maintain his separateness from others through these bodily processes. ${ }^{44}$ As in A Portrait of the Artist as a Young Man (1916), the narrative is occasionally interspersed with memories of hellfire and brimstone sermons, except in this novel they are from the 
Protestant tradition. Also reminiscent of this novel is his encounter with a prostitute: 'Returned to his hotel room, he scrubbed himself obsessively, then lay sleepless until morning, imagining already the first unclean symptoms' ${ }^{45}$ After this, he cannot perform for his legitimate partner, Minnie, preferring the feigned lust and masturbatory pleasure of a sex-worker. The frustration of the other characters in the novel often results in fantasies that involve bodily pleasure and trauma.

Barry Sloan states that, in Leitch's novel, 'men repeatedly stare at women, objectifying and reviling them as either ugly or sexually unattractive, or as little more than sluts who deserve to be raped'; he attributes this to a 'grotesque debasement of the Protestant principle of personal accountability'. ${ }^{46}$ This is not an adequate explanation of the complex way in which the visual operates in Stamping Ground. Feminist critical theory has complicated Mulvey's analysis and argued for the plurality of sites of the gaze and of gazers ${ }^{47}$ but her work is of particular use for an analysis of Leitch's work. Mulvey's essay sets out with the intention to 'discover where and how the fascination of film is reinforced by pre-existing patterns of fascination already at work within the individual subject and the social formations that have moulded him'. ${ }^{48}$ Mulvey makes the important distinction between Freud's analysis of the scopophilic gaze as active process in his Three Essays on the Theory of Sexuality (1905) and Lacan's narcissistic look and constitution of the ego: 'one implies a separation of the erotic identity of the subject from the object on the screen (active scopophilia), the other demands identification of the ego with the object on the screen through the speaker's fascination with and recognition of his like'. ${ }^{49}$ As Mulvey argues that patriarchy has, unconsciously, structured the film form, Leitch's self-critical awareness of the male gaze (while replicating certain structures Mulvey criticises) provokes questions about the structure and maintenance of certain forms of phallic authority in Northern Ireland. Hetty sees a photograph of Barbour on Minnie's mantelpiece but, instead of making him the object in her visual field, the picture makes her recall how he looks at her and how she is 'afraid of him and his bright gaze'.$^{50}$ In Leitch's novel, then, everyone takes up his or her place in the visual order and, by extension, the symbolic order.

Derrida states his anxieties about being asked to write an account of an exhibition of drawings with, 'It blinds me while making me attend the pitiful spectacle. By exposing me, by showing me up, it takes me to task but also makes me bear witness' (Emphasis original). ${ }^{51}$ The frequent change in narrative focus in Stamping Ground ensures that we never quite perceive a full account of any event in the narrative; rather it is recounted to us through observation, with that attendant 
bias and the changing narrative focus means the "body" of the text becomes fragmented. The representation of photography in the novel functions both to reinforce existing hierarchies and to ask questions of the way the characters negotiate their identities. Minnie's house is full of images of her dead, abusive father: 'There were photographs of him in nearly every room just to remind that, even though he had gone, he was still boss'. ${ }^{52}$ In addition to representing patriarchal dominance, the photographic is also used to discuss the sexuality of the boys as we are also told that 'The inside spread fluttered to the floor, another sea-nymph presenting her bum this time to the camera - he would have liked to have had a long look in peace himself at all that wet rounded flesh, felt sympathy for poor old Harvey, remembering the mail order catalogue slipped guiltily under a cushion at home, big smiling women modelling peach coloured knickers' ${ }^{53}$

Barbour Brown watches the local inhabitants with his binoculars while pretending to be bird-watching: 'For, if they only knew, these innocents in the heart of the country, they were his study and not the field creatures, they and their habits, much more fascinating than any dumb thing feeding, mating or dying under a sky' ${ }^{54}$ Writing about modernist literature and the visual, Karen Jacobs contends that the 'observer's claim to a transparent body is predicated, in other words, on the disavowal of its own embodiment along with the production of a reviled corporeality in the Other, whose embodiment at once qualifies it as an object of knowledge and disqualifies it from epistemological possibility and subjective complexity itself'. ${ }^{55}$ Barbour Brown's sense of himself and his place, then, is predicated on his objectifying the bodies of those around him; he can only perceive his own subjectivity as long as theirs is hollowed out. While John Wilson Foster has noted that violence seems the more prevalent narrative catalyst in Northern Irish fiction, voyeurism, as described by Mulvey, seems to take this role in Stamping Ground:

[Voyeurism] has associations with sadism: pleasure lies in ascertaining guilt (immediately associated with castration), asserting control and subjugating the guilty person through punishment or forgiveness. This sadistic side fits in well with narrative. Sadism demands a story, depends on making something happen, forcing a change in another person, a battle of will and strength, victory/defeat, all occurring in a linear time with a beginning and an end. ${ }^{56}$

This visual identification means that one does not have to fully engage with people, as they are at a remove, at the level of the image. Barbour cannot fully engage with Minnie but, at the level of observer and 
object, he can connect with the women he sees from his binoculars or the prostitute with whom he has a brief encounter. Barbour also considers the effect of the visual on the rest of the body: 'Did the body's equilibrium then become disturbed when one covered the eyes? ... Had blind men also then to adjust their gait, unconsciously correcting that veer? So, if a man suddenly, miraculously recovered his sight he would go tottering, the earth seeming to slant away beneath him, a possibly far worse sensation... ${ }^{57}$ In this novel there can be no real without the visual: Barbour muses on a photograph that memorialises his friends who went to the Somme and how his faulty heart saved him from their fate: 'It saved him from the worst horrors, namely the maiming, blinding or choking to death in the Belgian mudholes' ${ }^{58} \mathrm{He}$ obsessively collects the photographs of the town, taking a particular interest in school photographs: 'Every picture tells a story. Every one of those photographs did, at any rate, for there it was, a record for all who would see it, the face of the Valley and its generations'. ${ }^{59}$ Here is photographic is not just a pornographic aesthetic, but is also important to the collective memory of the community.

The object of Barbour's eventual dissolution of the real and the imaginary is Hetty Quinn. Throughout the novel, her wildness is emphasised: 'She just ran and ran, mental Hetty Quinn, down the village street under the moon like the wild thing she was' ${ }^{60}$ Hetty gives her friend some advice on what to do in the case of sexual assault: "“Come one step further and I'll prune your Willy John for you with this knife I've got here" ... What would it be like, she wondered, cutting it? Would it slice off clean, or would you have to saw at it like an old root? ${ }^{\prime 61}$ For Hetty, sexuality is about power and violence: who holds phallic authority and the best way to rid that authority of its agency. At a dance, Hetty doesn't want to suppress the sexual feelings she has, she wants to luxuriate in them: "The "sinful thoughts" that Minnie had warned her about rose in her thick and fast, but she wanted to hold them in her head, enjoying each to the full, sorry to feel it slide away before another took its place'. ${ }^{62}$ Hetty is keen to take her own sensual pleasure and is often filled with romantic thoughts but her fantasies jar with her experience of men's sexuality: 'They were all scum, the lot of them with their wee thing between their legs they were so proud of ${ }^{63}$ Her moment, dancing and fantasising she is in a Hollywood film, is in accordance with the other fantasists of the novel. She attempts to regain some sort of power over the boys by emasculating them at the dance, as she embarrasses them in front of a crowd with sexual slurs. Her refusal to take part in the symbolic order spurs them on to a second, more serious, attack at the end of the novel: 'Woman then stands in patriarchal culture as a signifier for the male 
other, bound by a symbolic order in which man can live out his fantasies and obsessions through linguistic command by imposing them on the silent image of woman still tied to her place as bearer, not maker, of meaning ${ }^{\prime}{ }^{64}$ Hetty attempts to impose meaning through language and failure to be the silent fantasy object. She returns their gaze with her acute observations on their sexual shortcomings and is punished for it.

Contrasted with Hetty's sense of herself is that of her assailants. Their evenings are presented as homosocial fun, as they drink their fill and sing crude songs about the loss of virginity which put them in high spirits: 'And it made them feel like rollicking blades, their laughter a warning to any girl they might come across, dear help her in her little cotton socks, dear help her, for they were the Terrible Three abroad and bent on divilment'. ${ }^{65}$ They recall their first encounter with Hetty: 'We touched you and we know you, our hands have been over you and we'll never forget, you'll never be a mystery again. Whenever you see us you'll know what we know and that we know ... But don't you know that you are ours now, that we have power over you, we broke through and plundered, we $\operatorname{did}^{\prime}{ }^{66}$ We are told that 'Harvey favoured the farm-yard approach naturally, seizing and mounting without preliminary. They both suspected his to have been very raw encounters with a raw kind of woman'. ${ }^{67}$ Again, sexuality is rendered as nothing more than glorified animal husbandry and the prized discrete body is depicted as subject to base lust. Political and religious ideology are seen as no match for the overwhelming need for sexual satiation.

At the end of the novel, the three boys sexually assault Hetty again? while Minnie sleeps upstairs. Crucially, this event is told to us through the eyes of Barbour Brown, who is watching from a window. He is not sure if the event is actually happening but still taking pleasure in the spectacle:

And as he devours her with his gaze, because he'll never be able to move closer, other faces now begin to swim up behind her. They rise slowly from the shadows, like those when a dream changes almost imperceptibly to a nightmare. He's seeing them, yet can't bring himself to accept their three grinning ovals. They hover just at the back of the settee - a touch of reality somehow in that fact - but they must be his demons alone, for she does not turn round ... Something terrible is about to happen in the room, in his head? He knows it, and it begins, and not in his head, for this naked girl turns, sees the three and opens her mouth to scream. No sound reaches him and that is even stranger. He watches everything that happens. ${ }^{68}$ 
Watching, he tells himself it is some sort of purgatorial test devised for him: 'Like a glutton forced to eat sweetmeat after sweetmeat he feels gorged already, but he cannot draw himself away. He watches, he consumes. Every bedroom tableau he has ever spied upon, country wives of every shape and size, dressing, undressing, posing, exposing, flesh by the acre, pink silk, but mainly flannelette, alas, that too, all nothing beside this'. ${ }^{69}$

As they begin to assault her (exactly what occurs is only partially rendered; we are not sure if there is a failure of ejaculation or other forms of penetration), Hetty bites Harvey but he wants to subdue her will, like a beast of the field to be tamed. When we are party to her thoughts, she is clear that this is violation: 'Murders run in her mind, crimes committed by men the worse for drink, or maddened by the moon. She's thinking such things but still she can't believe they might be happening to her, for she grits her teeth and fights back, but no account will she yell. She tells herself that' ${ }^{70}$ Her silence proves disorientating to both the boys and the voyeur at the window, as she has been so vocal throughout the novel. The encounter between the wild girl and the country boys, with the voyeuristic teacher watching, raises some difficult questions. With whom, do we, as readers, identify? Does the author want Hetty to get her comeuppance for her pride? Does he want to implicate us for knowing the guilty secrets that permeate Ulster communities and go unspoken? Hetty is quite clear in the passage above, that a crime is happening to her, and her perception is contrasted with Barbour Brown's as he continues to watch, pressed up against the window: 'Beyond the glass the love struggle continues - a composition of moving limbs, sometimes a starfish, sometimes a heaving knot or mound, but everchanging, always throwing out and back at him ingenuities'. ${ }^{71}$ Writing about European art, John Berger notes that 'He is the spectator in front of the picture and presumed to be a man. Everything is addressed to him. Everything must appear to be the result of his being there. It is for him that the figures have assumed their nudity. But he, by definition, is still a stranger - with his clothes still on'. ${ }^{72}$ Barbour Brown has internalised the power dynamics of this gaze and presumes that this physical spectacle has been put on for him. It is only when he begins to identify with the assailants that he can recognise what is happening:

He saw the boys' faces and their expression as if for the first time, and he was appalled, not at what he read there, but at his own realization that he could suddenly identify. The word shocked. He was witnessing a crime ... He hadn't allowed himself to recognize the cruelty in that tableau before, but it cried out to him now all right. ${ }^{73}$ 
He then realises that watching is not his pleasure, that this scene has not been created just for him, but rather that it is his punishment to watch forever, implicitly violating this girl who was in his charge when he was a school-teacher. Steve Neale, in his 1983 essay 'Masculinity as Spectacle' developed Laura Mulvey's analysis of the gendering of the gaze, arguing that the male body presented as object enacts a moment of crisis, with narcissistic identification with the ego ideal on screen. Barbour's crisis moment comes due to the presence of another male figure to identify with in his usually binarised scheme of looking. He is deeply destabilised by his rapt fascination with viewing another man's sexual pleasure.

In Irish literature, and particularly Northern Irish literature of this period, violent sexual encounters are often seen as metonymic for the political situation. This is most explicit in Seamus Heaney's 'Act of Union': 'And I am still imperially/ Male, leaving you with the pain, / The rending process in the colony, / The battering ram, the boom burst from within' ${ }^{74}$ Clair Wills discusses the use of this trope: 'The Act of Union becomes a struggle between primitive, landed, situated femininity and rational, social, organized masculinity which creates the inhabitants of the bastard province Northern Ireland'. ${ }^{75}$ However, in this encounter it is not Britain 'raping' Ireland but rural Protestants defiling one of their own. If Leitch is making a political point with this encounter, though, it is certainly a difficult one. This is the first novel Leitch published after his move to England from Northern Ireland, and the dour erotics of his first novels give way to something altogether darker. There is an argument to be made that Leitch reads extreme brutality as an inevitable consequence of sexual frustration in rural life, which women survive best by sexually acquiescing. On the other hand, Hetty and Barbour Brown both identify the act as a crime. It is this ambiguity that marks it out from later fiction by authors such as Joan Lingard, Bernard MacLaverty, Robert McLiam Wilson, and Glenn Patterson, where love and sex are the thing that can civilise us in times of political strife, and aligns it more with the work of Eoin McNamee wherein hierarchies of power, for better or usually worse, are played out in the sexual arena. This rather complicates Patterson and Wilson's aesthetic/ethical dimension from those complementary reviews in Fortnight and makes Leitch's work worth of more sustained attention.

Hetty does not trust her own perception of events and requires a mirror to inspect her victimised body. As Barbour Brown has internalised the politics of visual culture, so Hetty has internalised her own role in the visual/symbolic order: 'Some tears shed - in spite of herself - various bruises in various parts, one or two scratches, but of course worst of all the feel still with her, a damp sticky kind of feeling. 
She'd love a bath, and a mirror to examine herself all over. Nothing else, just that ${ }^{\prime}{ }^{76}$ Her desire throughout the novel to usurp the phallus, to cut it off or to diminish its authority, has come to fruition as she thinks: 'How the mighty have fallen, she thought. No lead in your pencil at all, Mack McFarlane'. ${ }^{77}$ This second assault troubles and humiliates her a lot less than the first encounter. Leitch seems to suggest that, after her rape, Hetty has managed to possess the phallus she was so obsessed with cutting off earlier in the novel. By being violated, by enduring, she has robbed the phallus of agency and, as the keeper of its secrets, she has gained power over it: 'So that's what it's all about, that's what men are after, all they're after, that ... A big rough girl who gave as good as she got. She didn't think she was pregnant, common savvy told her nothing could possibly come out of that daft performance. All that pushing to no avail. Just because they had what they had they couldn't rest until they put it to use, but for all it meant to her it might as well be something the cat brought home'. ${ }^{78}$ Alison Young discusses the film The Accused as the central character aims to have those who watched her rape prosecuted, with her lawyer aiming to prove their complicity in her attack:

Since its presence within the film means that members of the audience watch the rape as much as the individuals in the bar watch it, we must then consider the extent to which, to use the film's terms, the audience member watches as a witness to a crime, with the capacity to testify to its brutality, or as a spectator, able to find entertainment in what is depicted. ${ }^{79}$

Stamping Ground attempts to negotiate these ideas for both Barbour Brown as watcher, and for us as readers. Barbour initially positions himself a spectator but the process of identification makes him a witness. When he loses this distinction, when the boys chase after him, he is reduced to a pitiable old pervert, who attempts to regain his authority in a manner even he deems pathetic: 'I am old enough to be your grandfather, he called. -I saw Gladstone once'. ${ }^{80}$ In this novel, it is the violation by sight that is the most troubling, more so than actual physical penetration. There is little doubt that Leitch reserves censure in the novel for Barbour rather than the boys, as he has the potential to be an ethical witness yet refuses this in favour of his own sexual gratification, as he ends the book with: 'The Devil himself had entered her while she was undressed, she told them. She had suffered his lewd gaze upon her while her limbs had turned to water... The maid replied: 'It was the night-walker. It was he who entered me... ${ }^{\prime 81}$

If Mulvey has illuminated how the unconscious of patriarchy has structured film form then Leitch has examined how this is enacted 
in rural Ulster society through his co-opting of the visual aesthetic in Stamping Ground, where the visual signifies ideological dominance. In Leitch's work, the penis stands in for phallic authority and, by extension, Unionist hegemony and moral repression. Leitch's diagnosis of the failure of this dominant ideology is rendered in the failure to perform at critical moments. As in McGahern's work, Leitch draws attention to the problems and limits of patriarchal agency, ${ }^{82}$ but the critique of society replicates the structures of patriarchy by using female characters as a foil against this symbolic dominance. This is analogous with Heaney's tapping into the myth of the eternal feminine in North, in such poems as 'Act of Union' and 'Punishment', but to different political effect. Northern Irish fiction, then, can offer a space for a radical critique of the sectarian ideology and political fanaticism as long as one does not expect any destabilising of gender binaries. Leitch invites us, in Stamping Ground, to consider and critique patriarchal agency that is abusive to women and limiting to men.

\section{NOTES}

1. I would like to thank Shaun McDaid, Sean Farrell, Margaret Mills Harper and David Coughlan for their generous help and advice during the writing of this article.

2. Glenn Patterson 'Butcher's Tools', Fortnight (September 1994), p.43.

3. Robert McLiam Wilson, 'Rhythm Method' Fortnight (September 1994), p.31.

4. Robert McLiam Wilson, 'Rhythm Method', p. 31.

5. Maurice Leitch, Interview, Banned in Ireland (London, Routledge, 1990), p. 100.

6. Maurice Leitch, Interview, Banned in Ireland (London, Routledge, 1990) pps.97-108, p.108.

7. Maurice Leitch, Banned in Ireland, p.100.

8. Maurice Leitch, Banned in Ireland, pps. 99-100.

9. John Wilson Foster, Forces and Themes in Ulster Fiction, (Dublin: Gill and Macmillan, 1974), p.268.

10. Michael Parker reads The Liberty Lad, productively, against the backdrop of the failure of Liberal O'Neillism in the 60s and offers the novel as a critique of Unionist intransigence in Northern Irish Literature 1975-2006: The Imprint of History (Basingstoke: Macmillan, 2007).

11. There is a growing body of criticism on Unionist communities in the pre-Troubles period: Gillian McIntosh's The Force of Culture: Unionist identities in Twentieth-Century Ireland (Cork: Cork University Press (1999) deals well with the use of literature in the construction of a regional Ulster identity. Jane McCaughey's Ulster's Men: Protestant Unionist Masculinities and Militarization in the North of Ireland (Kingston: McGillQueen's University, 2012) offers vital context for an understanding of the development of Unionist men's identity in the twentieth century.

12. See Barry Sloan, Writers and Protestantism in the North of Ireland (Dublin: Irish Academic Press, 2000) and Barry Sloan, 'The Remains of Protestantism in Maurice Leitch's Fiction', Irish Fiction since the 1960s, Edited by Elmer Kennedy-Andrews (Gerrards Cross: Colin Smythe, 2006), pps.247-262.

13. Barry Sloan, 'The Remains of Protestantism', p.260.

14. Maurice Leitch, Stamping Ground, p.111.

15. Neil Jarman, 'Intersecting Belfast', Landscape, Politics and Perspectives, (Oxford, Berg, 1993), p.134. 
16. Seamus Heaney, 'Act of Union', North (London: Faber and Faber, 1975), p.49.

17. Jonathan Allison argues this point in 'Patrick Kavanagh and the Anti-Pastoral' in The Cambridge Companion to Contemporary Irish Poetry (Ed. Matthew Campbell, Cambridge: CUP, 2003).

18. George O'Brien, 'Contemporary Prose in English: 1940-2000', The Cambridge History of Irish Literature, (Cambridge, Cambridge UP, 2006), pp.438-9.

19. Frank Glass is also the name of the protagonist in The Liberty Lad, and the chronology would place him as teenage during Stamping Ground's 1950's setting. Glass becomes the victim of sexual harassment from a married man in order to get a promotion.

20. Maurice Leitch, Stamping Ground, p.4.

21. Maurice Leitch, Stamping Ground, p.6.

22. Maurice Leitch, Stamping Ground, p.11.

23. Maurice Leitch, Stamping Ground, p.14.

24. Paul Bew, Peter Gibbon, Henry Patterson , Northern Ireland 1921-2001 (London: Serif, 2001), p.106.

25. Reprinted as Laura Mulvey, 'Visual Pleasure and Narrative Cinema', Visual and Other Pleasures (Basingstoke: Macmillan, 1989), pps.14-28, p.20.

26. Laura Mulvey, 'Visual Pleasure and Narrative Cinema', p.21-22.

27. Jacques Derrida, Archive Fever (Chicago: University of Chicago Press, 1996), pp.1-3.

28. Maurice Leitch, Stamping Ground, p.30.

29. Maurice Leitch, Stamping Ground, p.30.

30. John Wilson Foster, Forces and Themes, p.254.

31. John Wilson Foster, Forces and Themes, p.255.

32. The complicity of the Catholic Church in the abuse of children and the persecution of unmarried mothers is well detailed in Diarmuid Feritter's Occasions of Sin: Sex and Society in Modern Ireland (London: Profile Books, 2009).

33. Longley, The Living Stream, p.187.

34. Maurice Leitch, Stamping Ground, p.41.

35. Maurice Leitch, Stamping Ground, p.198.

36. Ferriter, p.227.

37. Maurice Leitch, Stamping Ground, p.35.

38. Maurice Leitch, Stamping Ground, p.31.

39. Maurice Leitch, Stamping Ground, p.94.

40. Julia Kristeva, Powers of Horror: An Essay on Abjection (New York: Columbia, 1984), p.71.

41. Julia Kristeva, Powers of Horror, p.71.

42. Maurice Leitch, Stamping Ground, p.31.

43. Maurice Leitch, Stamping Ground, p.32

44. Hetty also has fantasies about her body which revolve around being captured by the Gestapo and of having medical conditions. She fantasises about getting on a bus to the city to be met by a handsome man in a white car who would buy her perfume, shoes, jewellery and 'a little fluffy dog like the one Gloria Grahame had in that picture she had once seen', Stamping Ground, p.19.

45. Maurice Leitch, Stamping Ground, p.183.

46. Barry Sloan, 'The Remains of Protestantism', p.248

47. See, in particular, Steve Neale's 'Masculinity as Spectacle', Screen 24, 6 (1983), Carol J. Clover's Men, Women and Chainsaws (Princeton: Princeton University Press, 1992), and Kaja Silverman's Male Subjectivity at the Margins (New York: Routledge, 1992).

48. Laura Mulvey, 'Visual Pleasure and Narrative Cinema', p.14.

49. Laura Mulvey, 'Visual Pleasure and Narrative Cinema', p.18.

50. Maurice Leitch, Stamping Ground, p.21. 


\section{IRISH UNIVERSITY REVIEW}

51. Jacques Derrida, 'From Memoirs of the Blind', The Derrida Reader: Writing Performances, Ed. Julian Wolfreys (Edinburgh: Edinburgh University Press, 1998), p.172

52. Maurice Leitch, Stamping Ground, p.20.

53. Maurice Leitch, Stamping Ground, p.89.

54. Maurice Leitch, Stamping Ground, p.27.

55. Karen Jacobs, The Eye's Mind: Literary Modernism and Visual Culture (New York: Cornell University Press, 2001), pps.1-2

56. Laura Mulvey, 'Visual Pleasure and Narrative Cinema', p.21-22.

57. Maurice Leitch, Stamping Ground, p.99.

58. Maurice Leitch, Stamping Ground, p.101.

59. Maurice Leitch, Stamping Ground, p.158.

60. Maurice Leitch, Stamping Ground, p.121.

61. Maurice Leitch, Stamping Ground, p.109.

62. Maurice Leitch, Stamping Ground, p.116.

63. Maurice Leitch, Stamping Ground, p.119.

64. Laura Mulvey, 'Visual Pleasure and Narrative Cinema', p.15.

65. Maurice Leitch, Stamping Ground, p.129.

66. Maurice Leitch, Stamping Ground, p.131.

67. Maurice Leitch, Stamping Ground, p.131.

68. Maurice Leitch, Stamping Ground, p.195.

69. Maurice Leitch, Stamping Ground, p.199.

70. Maurice Leitch, Stamping Ground, p.197.

71. Maurice Leitch, Stamping Ground, p.199.

72. John Berger, 'Ways of Seeing', The Feminism and Visual Culture Reader, Ed. Amelia Jones (New York, Routledge, 2003), p.39.

73. Maurice Leitch, Stamping Ground, p.200.

74. Seamus Heaney, 'Act of Union', p.49.

75. Clair Wills, Improprieties: Politics and Sexuality in Northern Irish Poetry (Oxford, Oxford University Press, 1993), p.69.

76. Maurice Leitch, Stamping Ground, p.202.

77. Maurice Leitch, Stamping Ground, p.203.

78. Maurice Leitch, Stamping Ground, p.201.

79. Alison Young, The Scene of Violence: Crime, Cinema, Affect, (New York, Routledge, 2010), p.34.

80. Maurice Leitch, Stamping Ground, p.206.

81. Maurice Leitch, Stamping Ground, p.209.

82. While John McGahern's Amongst Women (London: Faber, 1990) is his most sustained critique of the patriarchal agency in of the Irish state, the theme resonates through his oeuvre. A compelling analysis of this is Antoinette Quinn's 'A Prayer for My Daughters: Patriarchy in "Amongst Women" The Canadian Journal of Irish Studies 17.1 (1991) 79-90. 